\title{
Arctic Plants, Ecosystems and Strategies
}

\author{
PHILIP L. JOHNSON ${ }^{1}$
}

The expansion of both the rate and the impact of man's well-oiled technology have made his concern and understanding of the entire biosphere relevant, and indeed essential. The amount of critical knowledge about himself as well as his environment and resource base has, unfortunately, not been his prime concern nor is the amount of information required to operate "spaceship earth" readily attainable. We do not now know the minimum number of kinds of organisms required for man's survival and for the orderly regeneration, regulation and selfcleansing necessary to perpetuate any ecosystem. There are many ample examples of misbehaving systems with unstable epidemic populations, declining productivity, and polluted or toxic environments.

What do we know and what do we need to know about the structure, function, and adaptive strategy of arctic tundra ecosystems? By ecosystem I refer to a unit of landscape, an ecological system composed of associated plants, animals, microbes and their environment. Such systems are open not closed, they are dynamic not static, the biota co-exist and interact with their environment and with each other. The organisms have evolved various adaptions and the ecosystem has developed complex interdependencies in order to survive. In developing a perspective rather than a review, I shall concentrate on plants, the primary biological producers of any ecosystem.

\section{ARRAYS IN TIME}

Plants and vegetation mixtures are arrayed in both time and space. Their evolution and migration over geologic time scales contribute to their present spatial distribution.

\section{Succession}

Shorter-term change in plant arrays, particularly following disturbance of the natural assemblage, is due to ecological succession. Succession is one of the more important concepts for ecosystem management and manipulation in temperate latitudes, but the phenomenon is poorly understood for tundra ecosystems (Churchill and Hanson 1958). Fragmentary evidence is accumulating that succession does occur as new habitats are colonized (Bliss and Cantlon 1957; Britton 1957; Viereck 1966) or in response to freeze-thaw activity in tundra terrain (Benninghoff 1952; Hopkins and Sigafoos 1951; Sigafoos 1952; Johnson and Billings 1962; Troll 1958). We know little about the rates of vegetative recovery

1Institute of Ecology, University of Georgia, Athens, Georgia, U.S.A. 
or succession in various types of tundra. There are observations at Barrow that suggest reinvasion of some upland vehicle trails within five years. There are other examples of irreversible destruction of tundra in which albedo is lowered from an average of 20 per cent to 10 per cent or lower and the heat coefficient is altered so that thermokarst processes are activated and shallow ponds replace meadows.

\section{Redistribution and Migration}

Modern vegetation assemblages began with topographic changes imposed by uplift and the resulting climatic shifts during the late Tertiary and Pleistocene. These vegetation patterns continued to shift and differentiate in response to repeated glaciation. Two major sources of floral migration are especially significant to Alaska, the Bering Land Bridge and unglaciated refugia. There is increasing evidence that major elements of today's biota including man crossed the broad land bridge that spanned Bering Strait during the Wisconsin glacial period until about 11,000 B.P. (Péwé et al. 1965).

Reconstruction (Heusser 1965) of late- and post-glacial pollen spectra (Fig. 1) from the efforts of several investigators indicates that forested areas in Alaska contained about the same species as at present. Composition of arctic tundra

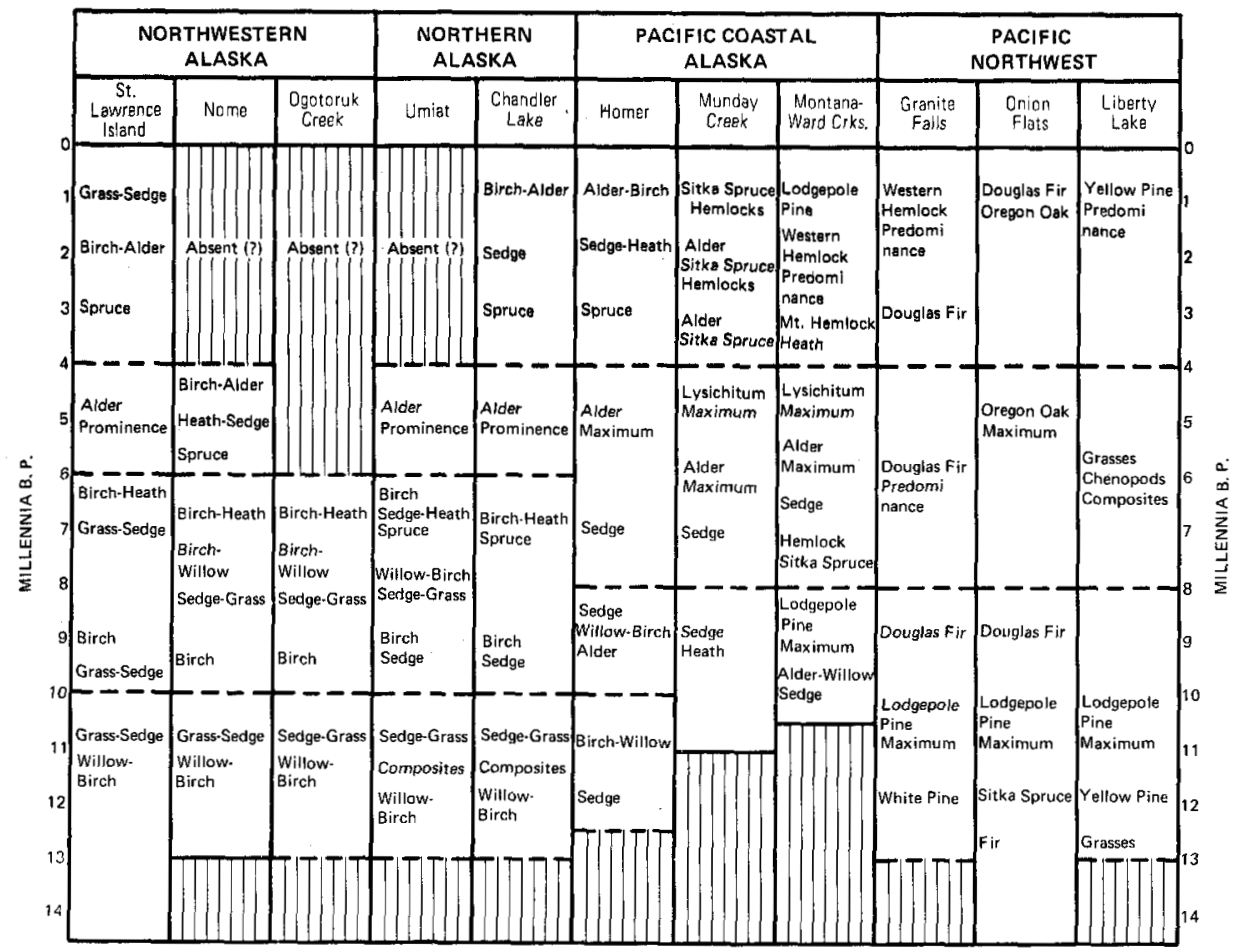

FIG. 1. Summary of late-glacial and postglacial vegetation for selected sections summarized by Heusser (1965). Vertical lines appearing at the bases of most columns cover intervals for which no record is available. Where they terminate above by a solid cross-line, the pollenbearing sediments are radiocarbon dated; dash cross-lines indicate age inference from regional dating. The upper portions of the sections from Nome, Ogoturuk Creek, and Umiat appear to be truncated (from Heusser 1966). 
evidently shifted from dominance by sedges, grasses and composites to birch shrubs that were subsequently invaded by alder at the thermal maximum.

Steere (1965) points out that of 500 bryophyte species known from the circumpolar Arctic, over 60 are considered restricted to the high Arctic, although far less endemism can be substantiated than formerly thought. The intriguing patterns of disjunct distribution of moss species suggest many close relationships with tropical rather than temperate flora. In combination with the known unglaciated habitats that persisted throughout the glacial epoch, these disjunct relationships suggest that many arctic mosses have remained essentially unchanged since Tertiary time.

The distribution and migrations of tundra flora continue to be objects of insight into Pleistocene events as well as evolutionary strategies. One clue is the frequency of polyploidy. These generalizations about multiple chromosome complements have emerged:

1) Arctic plants have substituted asexual for sexual reproduction particularly among perennial herbs under environmental stress; thus, polyploidy may not be limiting to perpetuation of the genotype.

2) The availability of new ecological niches, as following deglaciation or gross climatic change, favours establishment of polyploid species.

3) Polyploidy is generally thought to be a percentage of the flora inversely related to latitude in the northern hemisphere (Löve and Löve 1957).

4) Polyploids are considered more successful in extreme environments than their diploid relatives. Thus, arctic diploid species are interpreted as ancient arcticalpine genotypes occupying drier or more stable habitats including snowbed communities (Johnson et al. 1965). Polyploid species have spread out over the Arctic during post-glacial times and occupy sites with greater cryoturbation.

Johnson and Packer (1965) demonstrated for the Cape Thompson, Alaska, flora a correlation of polyploidy with an edaphic gradient. The polyploid frequency was lowest in warmer, drier, more stable habitats and increased with greater soil disturbance. Clearly, a regional percentage represents an integrated flora existing over the range of habitats available. The fact that polyploids are more successful than diploids in disturbed periglacial habitats prevalent during glacial periods, combined with the unglaciated condition of interior and northwestern Alaska in contrast to glaciated northern Europe, is of major significance in accounting for the lower frequency in European floras (Johnson and Packer 1965, Packer 1969).

The relationship of polyploid success to extreme environments is further supported by Packer's (1969) studies of the Canadian Arctic Archipelago. The frequency of polyploidy on 15 islands provides no evidence of a gradient correlated with latitude. Rather the observed distribution is more nearly associated with summer isotherms. That is, temperatures ameliorate toward the NE, SE and SW from Prince of Wales Island and polyploid frequency among dicots tends to decline accordingly from close to 70 to 50 per cent on Southampton Island. 


\section{ARRAYS IN SPACE}

\section{Vegetation Assemblages}

The arctic flora is now reasonably well known except for fungi. We are indeed fortunate to have the excellent flowering plant manuals of Hultén (1968) and Wiggins and Thomas (1962). Hultén includes 1,559 species of vascular plants in 89 families and 412 genera for the Alaska region. Spetzman (1959) lists 439 taxa in 53 families for the coastal plain, foothill and mountain provinces of the Alaskan north slope. There appear to be approximately 100 vascular species at Barrow, 250 species at Umiat (Britton 1957) and 300 species at Cape Thompson (Johnson et al. 1966). Of 220 species at Meade River, at least 84 are also found at Barrow and about 170 are common to Cape Thompson. The reduction in species diversity northward is more likely related to a reduction of ecological niches related to topographic and habitat diversity rather than simply intensification of climatic parameters.

Krog (1968) has recently provided an account of 348 species of macrolichens for Alaska. This compares with 375 species for Fennoscandia, although the list is certainly incomplete for Alaska. From existing records of lichen distribution Krog concludes the following composition:

Circumpolar species

Per cent

Disjunct species occurring in Eurasia and North America

Asiatic-North American species

North American west coast species

North American species with affinities in Southern Hemisphere

Descriptive accounts of vegetation of the Alaskan Arctic by Spetzman (1959), Johnson et al. (1966), Benninghoff (1952), Bliss (1956), Drury (1956), Hanson (1953), Hopkins and Sigafoos (1951), and Wiggins (1951) are particularly helpful. The classic, however, on arctic vegetation on the northern slope of Alaska continues to be Britton's (1957) eloquent description. Most of his observations and insights continue to be further documented and substantiated (i.e. Cantlon 1961; Clebsch and Shanks 1968; Pitelka and Schultz 1965). An elaboration (Table 1) of habitats and communities appropriate to coastal plain tundra with distinctive indicator species was developed from field studies at Meade River.

What emerges from the descriptions of arctic tundra is the impossibility of understanding tundra dynamics or even vegetation associations without a parallel examination of topographic microrelief, soils and thaw depths that collectively constitute the substrate for plant life. Accepting the three physiographic units generally recognized for the north slope, mountains, foothills and coastal plain, Cantlon (1958) proposed that within major regions three scales of topographic relief were important: macro-, meso-, and microrelief. Although he did not propose measurement units, these three scales are approximately on the order of hundreds to tens of metres, metres, and centimetres of vertical relief respectively. Such a concept is supported by the development of different soil types along topographic gradients that primarily reflect drainage and snow cover gradients (Brown 1966, 
TABLE 1. Physiographic habitats and ecological communities of Arctic Coastal Plain tundra in Alaska

\begin{tabular}{|c|c|}
\hline Physiographic Habitat & Community Type \\
\hline River Bars & $\begin{array}{l}\text { 1. Open pioneer communities } \\
\text { 2. Riparian willow } \\
\text { 3. River bar tundra }\end{array}$ \\
\hline River Cutbanks & $\begin{array}{l}\text { 4. Bluff (a) Turfy } \\
\text { (b) Sandy } \\
\text { 5. Wet slump slope } \\
\text { 6. Dry slump slope } \\
\text { 7. Snowbed gullies }\end{array}$ \\
\hline Sand Dunes & $\begin{array}{l}\text { 8. Active dunes } \\
\text { 9. Semi-stabilized dunes } \\
\text { 10. Stabilized dunes }\end{array}$ \\
\hline Streamside & $\begin{array}{l}\text { 11. Stream margin } \\
\text { 12. Streambank } \\
\text { 13. Floodplain }\end{array}$ \\
\hline Lakes and Ponds & $\begin{array}{l}\text { 14. Open water } \\
\text { 15. Emergent grass } \\
\text { 16. Aquatic sedges } \\
\text { 17. Wet sedge bog } \\
\text { 18. String bog } \\
\text { 19. Sphagnum hummocks } \\
\text { 20. Pond margins }\end{array}$ \\
\hline Low Centre Polygons and Ridges & $\begin{array}{l}\text { 21. Wet tundra } \\
\text { 22. Wet sandy flats } \\
\text { 23. Tussock tundra }\end{array}$ \\
\hline Polygon Troughs & $\begin{array}{l}\text { 24. Muddy troughs } \\
25 . \text { Peaty troughs } \\
\text { 26. Wet mossy troughs } \\
\text { 27. Sedge troughs }\end{array}$ \\
\hline Upland Tundra and Ridges & $\begin{array}{l}\text { 28. Lichen barrens } \\
\text { 29. High centre polygons } \\
\text { 30. Snowbed }\end{array}$ \\
\hline Disturbed Sites, Dry & $\begin{array}{l}\text { 31. Recently drained lake sediments } \\
\text { 32. Squirrel burrows } \\
\text { 33. Abandoned dwelling sites } \\
\text { (a) Moist } \\
\text { (b) Dry } \\
\text { 34. Airstrip and mine tailings }\end{array}$ \\
\hline Disturbed Sites, Wet & $\begin{array}{l}\text { 35. Drainage ditches } \\
\text { 36. Excavation ponds } \\
\text { 37. Caribou, other carcasses } \\
\text { 38. Vehicle trails }\end{array}$ \\
\hline
\end{tabular}

Tedrow and Cantlon 1958). Studies at Cape Thompson by Johnson et al. (1966) showed the relations of the principal plant communities to relief, soil type and permafrost (Fig. 2).

Attempts statistically to correlate vegetation type with parameters of the atmosphere or lithosphere in local areas generally produce positive correlations with thaw depth and soil moisture, but inconsistent results with other variables. Recent studies have attempted to examine complex relationships (Brown and Johnson 1965, 1966) but simple relationships do not yet exist. The accumulating information on arctic pedology and cryopedology (Brown 1965, 1966, 1967, 1969; Douglas and Tedrow 1961; Drew and Tedrow 1957; Hill and Tedrow 1961; Tedrow et al. 1958) is encouraging. An integrated view of plant-soil interactions may soon solidify, thanks particularly to the efforts of Tedrow and his associates. 


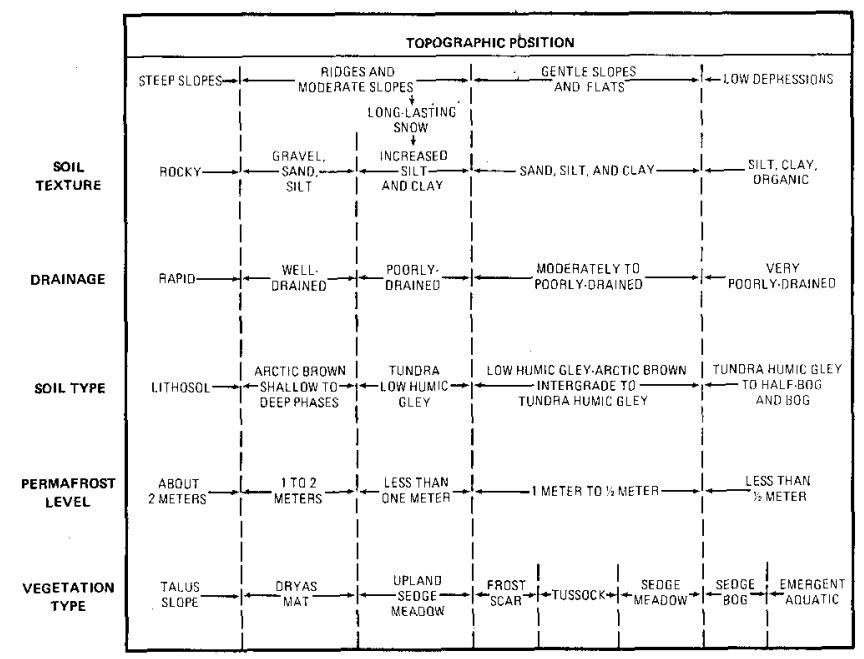

FIG. 2. Relationships between soil characteristics and vegetation along topographic gradients in the Ogoturuk Creek valley, Alaska (from Johnson et al. 1966).

In the interim the following major soil groups are recognized: Lithosol, Podzollike, Upland Tundra, Arctic Brown, Meadow Tundra, Half Bog, and Bog (Tedrow and Cantlon 1958, Tedrow and Brown 1968). There is also evidence for an arctic Rendzina and a shungite soil (Ugolini et al. 1963).

\section{STRUCTURE AND FUNCTION}

The vegetation of arctic ecosystems is comparatively simple in both composition and structure, although far more complex than is suggested to the uninitiated observer. Herbaceous perennials and low shrubs are the most abundant life form, annuals are rare or absent. Common morphological adaptations include: 1) Cushion or polster life form, 2) rosette life form, 3) leafy stemmed plants, 4) graminoid including tussock formation, and 5) prostrate, diminutive woody shrubs. Clearly these forms are a response (Bliss 1962a; Tikhomirov 1963) to climatic moderation close to the ground, even beneath seasonal snow. Tussock formation may also be advantageous for maximum solar interception at low sun angles characteristic of high latitudes.

\section{Carbohydrate Cycle}

Growth is rapid immediately following snow melt (Billings and Bliss 1959; Warren-Wilson 1960, 1966; Wager 1938). This is apparently possible because of the large amounts of carbohydrates and starch stored in roots, rhizomes and corms (Mooney and Billings 1960; Russell 1940b). It appears that the ratio of live standing above ground to live below ground biomass is about 1:5. Metabolism occurs at low growing season temperatures, near $0^{\circ} \mathrm{C}$. The short growing season of some 70 to 80 days requires that the yearly vital events be consummated in a short period (Fig. 3). Thus, food storage underground in herbaceous plants as carbohydrates or as lipids (Bliss 1962c) in old leaves of evergreen shrubs is characteristic of arctic and alpine plants. Asexual reproduction including apomixis 


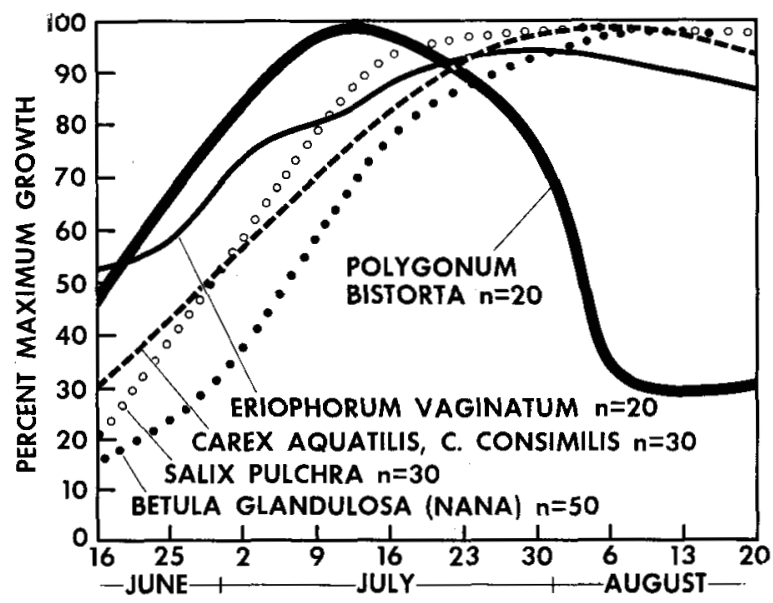

FIG. 3. Growth of 150 plants as evidenced by stem and leaf elongation as a percentage of maximum length at Meade River, Alaska, in 1966. By the third week of July, 90 percent of vegetative growth had occurred. The growth curve for Polygonum clearly indicates a period of growth followed by a flowering period, and then carbohydrate translocation to a thick rhizome as the leaves shrivelled.

and vivipary replaces sexual reproduction as a response to a shortened growing season or unfavourable climatic condition. We know comparatively little, however, about events that condition flowering or seed set in any given year. We do know that flower buds are usually pre-formed the previous growing season, but complete development and anthesis depends on temperature of the flowering year and some species may have a photoperiod requirement (Hodgson 1966). Seed dormancy is environmentally controlled, but seeds can remain viable for long periods of time at low temperature, since they require temperatures well above freezing for germination (Bliss 1958, Amen 1966). Optimum germination temperatures seem to be 20 to $30^{\circ} \mathrm{C}$., but seedling establishment commonly requires several years. Thus sexual reproduction is opportunistic and vegetative propagation is more reliable.

\section{Chlorophyll Content}

The distribution of chlorophyll in plant communities is one common parameter of diverse species and morphologies. Examination of chlorophyll per unit area at Meade River, Alaska (Tieszen and Johnson 1968) showed that mosses in dry sedge stands might contain over a third of this vital pigment, whereas in wet sedge stands chlorophyll was nearly all contained in Carex aquatilis. The amount of pigment in different communities including dry and wet sedge tundra, low shrub willow, and cotton grass tussock tundra $\left(0.32\right.$ to 0.77 g.m. $\left.{ }^{-2}\right)$ was highly correlated with the production of plant biomass. However, chlorophyll concentrations varied among different communities from $1.5 \mathrm{mg.g}{ }^{-1}$ in dry sedge tundra to $8.8 \mathrm{mg} \cdot \mathrm{g}^{-1}$ in wet sedge tundra on a dry weight basis. One suspects the opposite relationship for cellulose and other supporting tissues.

On a land area basis chlorophyll content is about the same in alpine (Bliss 1966) and arctic tundras as well as being similar to temperate herbaceous communities (Bray 1960). Within the same species there is more chlorophyll in leaves of arctic populations than for alpine populations (Billings and Mooney 1968). Mooney and Johnson (1965) using Thalictrum alpinum in growth chambers found that the 25 per cent higher pigment content in arctic populations was genetically controlled. 
Associated with adjustment in pigment content are wider but thinner leaves in certain arctic versus alpine plants (Tieszen and Bonde 1967). Billings and Mooney (1968) concluded that green pigment content was both genetically and environmentally conditioned. The lesser values for alpine populations are in clear contrast to arctic plants and also in contrast to lower elevation plants. Ultraviolet radiation is in part responsible for rapid breakdown of chloroplasts, but some species of plants may have too slow a rate of protochlorophyllide synthesis to keep ahead of photo-oxidation in bright light at low temperatures.

\section{Physiological Ecology of Plant Populations}

The experimental approach to processes in arctic and alpine plants and ecotypes of the same species has yielded an important insight into adaptation to severe environments at the species population level. From recent reviews of work by Bliss (1962b) and Billings and Mooney (1968) and their students the following conclusions seem justified:

1) Metabolism of the phenotypic plant is controlled by both genetic variation and by past and present environments. The actual diurnal and seasonal courses of photosynthesis and respiration are the result of complex interactions between genetic plasticity and environmental control.

2) Plants of arctic populations have a higher photosynthetic rate at lower temperatures and attain a maximum rate at lower temperatures than do alpine plants.

3) Arctic plants have higher respiration rates at all temperatures than do alpine plants.

4) Light saturation for arctic plants is reached at lower light intensity than in alpine plants. In Oxyria digyna populations grown in growth chambers at $20^{\circ} \mathrm{C}$, for example, northern populations $\left(61^{\circ} 23^{\prime} \mathrm{N}\right.$.), were shown to be saturated at 2,000 f.c. whereas southern latitude $\left(39^{\circ} 40^{\prime} \mathrm{N}\right.$.) high elevation plants were not saturated at 5,200 f.c.

5) There is a clinal increase in the photoperiodic requirements for flowering from southern to northern populations.

6) Arctic plants are much less tolerant of high temperatures than alpine plants. In demonstrating biochemical differences in the photosynthetic mechanism of the Hill reaction in Deschempsia caespetosa, Tieszen and Helgager (1968) support the same conclusions.

Thus there is strong evidence from different populations that suggests evolutionary adaptation to the specific light climate by adjustment in growth and flowering response, perennating bud formation and photosynthetic/respiration balance. The close relationship between tissue temperature and rates of photosynthesis and respiration strongly suggest that maximum daytime temperatures is the critical environmental factor distinguishing arctic and alpine gene pools from subarctic or subalpine populations (Billings and Mooney 1968). Although annual productivity is low, daily rates of carbon fixation during the peak of the growing season can be as high as most temperate herbaceous vegetation (Billings and Mooney 1968), ranging from 0.5 to $5.0 \mathrm{~g} . \mathrm{m}^{-2}$ day $^{-1}$ for shoots and perhaps up to 11 g.m..$^{-2}$ day $^{-1}$ if root productivity is included. 


\section{Tundra Ecosystems}

Holistic approaches to arctic ecosystems have been reported only recently. Gore and Olson (1967) attempted one of the first applications of systems models to account for the accumulation of organic matter in a British Eriophorum-Calluna bog. Johnson and Kelley (1969) have presented a carbon budget (Table 2) for an arctic coastal tundra ecosystem based on measurements of biomass and carbon dioxide flux (Table 3).

TABLE 2. Dry matter production in an arctic tundra ecosystem for a growing season ${ }^{1}$

\begin{tabular}{lcl}
\hline & g.m-2 & \multicolumn{1}{c}{ Source of Data } \\
\hline Gross Top Production, GTP & 109 & Chamber Measurements \\
Net Top Production, NTP & 82 & Harvested Plots \\
Net Root Production, NRP & 100 & Dennis 1968 \\
Estimated Net Production, NP & 182 & NTP + NRP \\
Top Respiration, TR & 27 & GTP-NTP \\
Root Respiration, RR & 135 & Douglas and Tedrow 1959 \\
Primary Respiration, R & 162 & TR + RR \\
Gross Primary Production, GP & 344 & NP + R \\
Litter, L & 273 & Harvested Plots \\
\hline
\end{tabular}

'From: Johnson and Kelley 1969

TABLE 3. Annual carbon flux in arctic tundra

\begin{tabular}{|c|c|c|c|c|c|}
\hline \multirow[t]{2}{*}{ Atmosphere } & & \multicolumn{4}{|c|}{3770 g. $\mathrm{CO}_{2} \mathrm{M}-2$} \\
\hline & & $\begin{array}{c}10.8 \\
\downarrow \\
\text { Gross Photo }\end{array}$ & & $\begin{array}{c}5.6 \% \\
\text { Net Storage }\end{array}$ & 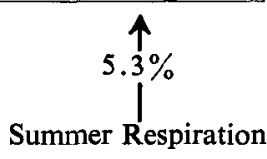 \\
\hline \multirow[t]{2}{*}{ Vegetation } & $\begin{array}{l}\text { Tops } \\
\text { Roots, Rhizome }\end{array}$ & $\begin{array}{l}109 \\
235\end{array}$ & $\begin{array}{l}= \\
=\end{array}$ & $\begin{array}{r}82 \\
100\end{array}$ & $\begin{array}{r}27 \\
135\end{array}$ \\
\hline & Primary Production & 344 & $=$ & 182 & 162 \\
\hline
\end{tabular}

Sufficient data have been accumulated by a spectrum of investigators at several tundra sites to justify pooling and synthesizing the available data before much further field investigation is undertaken. Primary productivity (Bliss 1962a) in tundra ponds at Barrow was determined by Kalff (1967a) to be only 380 to $850 \mathrm{mg} . \mathrm{m}^{-2}$ year $^{-1}$, but to be 8.5 g.m. ${ }^{-2}$ year $^{-1}$ for Imikpuk, a freshwater lake (Kalff 1967b). Hobbie (1964) reports 6.6 to 7.5 g.m. ${ }^{-2}$ year $^{-1}$ in oligotrophic Lake Schrader and even less for Peters Lake. Thus freshwater productivity is relatively low primarily because of a short growing season and perhaps because of low nutrient availability.

Pieper studied above ground biomass and chemical composition of Dupontia meadows, and Dennis has measured standing crops of above as well as below ground vegetation in several communities at Barrow. At Barrow net shoot production varies from 3 to 97 g.m. ${ }^{-2}$ year $^{-1}$ depending on the site and grazing intensity. Various nutrient cycling studies are reported by Barsdate (1966), Brown et al. 
(1968), Kalff (1968), Likens and Johnson (1968), Pitelka and Schultz (1965), and Russell (1940a). While considerable data are now available on concentrations of the more important minerals little is known about their rates of uptake, retention and release.

Much is known about the more important animals at higher trophic levels in the food web (Holmes 1966; Holmes and Pitelka 1968; Bohnsack 1968; Mayer 1954; Mullen 1968; Pitelka 1957, 1959; Pitelka et al. 1955; Thompson 1955; Weber 1950). Considerable macro- and microclimatic data are available from Barrow and certain other arctic sites. Thus we can begin to construct a general ecosystem model for tundra with appropriate compartments and pathways for transfer of energy and materials. Mathematical equations can then be written to express the rate functions of such a network in order to achieve a predictive model.

A model is only a concept, a vehicle for stating a complex hypothesis, its validity and applicability must be tested. That, in fact, is the intent of the tundra project in the International Biological Program. From the beginnings made in other biomes, and by the tundra project, it is possible to foresee a variety of models. Regional models will express the differences between major tundra types such as British blanket bog or a Finnish lichen-reindeer system. Other models will express in greater detail an individual process such as the functioning of the photosynthetic apparatus. To the degree that predictive ability is generated by these models, a powerful tool for landscape management will be created. We have learned elsewhere that new insight into the complexities of whole ecosystems is gained through stressing the system by some manipulation. Often these stresses are created inadvertently, but it seems very likely that future field strategy will be less observational and more experimental.

From the Arctic, the ecologist is learning the many facets of a complex natural system, how and where it originated, how it develops, how it survives. It is a great natural system in which the first Americans also arrived, evolved and survived. By examining the anatomy and metabolism of tundra, which is simpler in diversity, architecture, and number of interactions than those at lower latitude, we strive to learn principles applicable to those more complex systems. Do the conclusions suggested from experience elsewhere fit the Arctic? Usually not without modification. The unique stresses of the arctic environment from day length to permafrost afford additional dimensions to learn tolerances and limitations of organisms. Furthermore, as man and his technology add new stresses to an already fragile system we can learn about processes at work by the response of these individuals, populations and ecosystems.

\section{STRATEGY FOR LIVING}

With what strategy should society view the Arctic? The wealth of the Arctic does not glitter; yet Robert Service associated it with exploration. Tundra has long been one of those few remaining areas in this world which man could ponder or disregard at his leisure. Are we about to witness the exploitation of the Arctic? Robert Weeden (1969) thinks so, as he explained in a recent address on Arctic Oil. So do those concerned with the economy of Alaska, but from different moti- 
vations. As Garrett Hardin (1968) expressed it, in a thought-provoking article, "The tragedy of the commons" is upon us. By the "commons" he meant that village pasture available for the use of all citizens. This right of mutual ownership was stressed by too many citizens with too many grazing cows, and so we have abandoned the commons for food gathering. We fence and post land, we place restrictions on an increasing number of human activities from hunting, waste disposal, parking, and building, to mining. We are trying to cope with regulations for pesticide applications, noise abatement, and radioactive contamination. Each new enclosure of the commons infringes on somebody's freedom. How much longer can we preserve the freedom to breed, for it will soon beget misery. As both Hardin (1968) and Allen (1969) emphasized again recently, the human population problem has no technological solution. What strategy can we soon invoke to assure adequate food, space and sanity among men? Allen (1969) correctly observes, "The wild creatures of this earth have survived because each performs a useful function in a reasonably stable ecosystem. Any living thing that is too successful destroys the sources of its livelihood and disappears with the community on which it depends. Man's vast power play in using, if not inhabiting, nearly every environment on this planet could be self-defeating if he does not have the insight to impose his own controls and work for that necessary stability in his ecosystem."

The value systems developed in our society have a Judeo-Christian basis, our science is distinctly western. Its dominant attitude is egocentric about man and exploitive about nature. Is not this what we mean when we speak of developed country? In a provocative article on "The historical roots of our ecological crisis," White (1967) concludes that, "Despite Darwin, we are not, in our hearts, part of the natural process. We are superior to nature, contemptuous of it, willing to use it for our slightest whim.... Hence we shall continue to have a worsening ecologic crisis until we reject the Christian axiom that nature has no reason for existence save to serve man."

How then can we view the world and arrive at apptopriate strategies? Certainly not by extending the doctrine of prior appropriation, a legal concept that developed in relation to water resources. A point of view that integrates ecological and socioeconomic systems is essential. Man's physical, physiological and psychological requirements will be fulfilled only if ecological, economic, engineering, educational and ethical thoughts are combined. The thoughtful reader will, I hope, recognize that I refer to a philosophy that runs far deeper than the virtuous conservation ethic.

Fortunately, there is increasing awareness among the public, an anxious involvement among professionals and some frantic rhetoric from a few of our public administrators. The noise is not too great to listen or learn. Technology assessment, environmental monitoring, and regional planning are necessities. But one of the soundest bases for coping with our environment and its resources is probably the development of ecosystem zoning (Odum 1969) as a rational means of resource and space allocation; this we have already begun to do in urban ecosystems. We have sufficient information to plan some ecosystems wisely for certain activities. Clearly the nation needs a greatly expanded ability to acquire 
ecological information in a coherent, integrated and purposeful manner. Multidisciplinary research programs organized in response to the International Biological Program could very well forecast in a small way the beginnings of a new, more rational and more beneficial strategy for living.

\section{REFERENCES}

ALLEN, D. L. 1969. Population, resources, and the great complexity. 34th North American Wildlife and Natural Resources Conference. 11 pp. (mimeo).

AMEN, R. D. 1966. The extent and role of seed dormancy in alpine plants. Quarterly Review of Biology, 41: 271-81.

BaRSDATE, R. J. 1966. Pathway of trace elements in arctic lake ecosystems. Annual Progress Report. U.S. Atomic Energy Commission contract AT(04-3)-310. 43 pp.

BENNINGHOFF, w. S. 1952. Interaction of vegetation and soil frost phenomena. Arctic, 5: 34-44.

BILlings, W. D. and H. A. MOONEY. 1968. The ecology of arctic and alpine plants. Biological Review, 43: 481-529.

BLISs, L. C. 1956. A comparison of plant development in microenvironments of arctic and alpine tundras. Ecological Monographs, 26: 303-37.

- 1958. Seed germination in arctic and alpine species. Arctic, 11: 180-88.

1962a. Net primary production of tundra ecosystems. In: Die Stoffproduktion der Pflanzendecke, ed. H. Lieth. Stuttgart: Fischer Verlag: 35-46.

1962b. Adaptations of arctic and alpine plants to environmental conditions. Arctic, 15: 117-44.

1962c. Caloric and lipid content in alpine tundra plants. Ecology, 43: 753-57.

1966. Plant productivity in alpine microenvironments on Mt. Washington, New Hampshire. Ecological Monographs, 36: 125-55.

BLISS, L. C. and J. E. CANTLON. 1957. Succession on river alluvium northern Alaska. American Midland Naturalist, 58: 452-69.

BOHNSACK, К. К. 1968. Distribution and abundance of the tundra arthropods in the vicinity of Pt. Barrow, Alaska. Washington, D.C.: Arctic Institute of North America. Final report of subcontracts ONR 308-321, $111 \mathrm{pp}$. (mimeo).

BRitTon, M. E. 1957. Vegetation of the arctic tundra. In: H. P. Hansen, ed. Arctic Biology. Corvallis: University of Oregon Press: 26-61.

BRAY, J. R. 1960. The chlorophyll content of some native and managed plant communities in central Minnesota. Canadian Journal of Botany, 38: 313-33.

BRown, J. 1965. Radiocarbon dating, Barrow, Alaska. Arctic, 18: 37-48.

1966. Ice-wedge chemistry and related frozen ground processes, Barrow, Alaska. In: Proceedings Permafrost International Conference, 1963. Washington, D.C.: NAS-NRC Publ. 1287. pp. 94-98.

1967. Tundra soils formed over ice wedges, northern Alaska. Soil Science Society of America Proceedings, 31: 686-91.

1969. Soil properties developed in the complex tundra relief of northern Alaska. Builetyn Peryglacjalny. (In Press).

BROWN, J. and P. L. JoHNSON. 1965. Pedo-ecological investigations, Barrow, Alaska. U.S. Army CRREL Technical Report 159.32 pp. 
1966. U.S. Army CRREL Topographic Map Barrow, Alaska. U.S. Army CRREL Special Report 101.

BROWN, J., S. L. DINGMAN, and R. I. LEWELLEN. 1968. Hydrology of a drainage basin on the Alaskan coastal plain. U.S. Army CRREL Research Report $240.18 \mathrm{pp}$.

CANTLON, J. E. 1958. Differences in plant abundance and cover in relation to macro-, meso-, and micro-relief. Washington, D.C.: Arctic Institute of North America. Progress Report of subcontracts ONR 208, 18 pp. (MS.).

1961. Plant cover in relation to macro-, meso-, and micro-relief. Washington, D.C.: Arctic Institute of North America. Final report of subcontracts ONR 208-212, 128 pp. (MS.).

CHURChILL, E. D. and H. C. HANSON. 1958. The concept of climax in arctic and alpine vegetation. Botanical Review, 24: 127-91.

CLEBSCH, E. E. C. and R. E. SHANKS, 1968. Summer climatic gradients and vegetation near Barrow, Alaska. Arctic, 21: 161-71.

DOUGLAS, L. A. and J. C. F. TEDRow. 1961. Tundra soils of Arctic Alaska. 7th International Congress Soil Science Transactions, Comm. V., Vol. IV: 291-304.

DREW, J. v. and J. C. F. TEDRow. 1957. Pedology of an Arctic Brown profile near Point Barrow, Alaska. Soil Science Society of America Proceedings, 21: 336-39.

DRURY, W. H., JR. 1956. Bog flats and physiographic processes in the upper Kuskokwim River region, Alaska. Cambridge: Gray Herbarium, Harvard University Contribution 178. $130 \mathrm{pp}$.

GORE, A. J. P. and J. S. OLSON. 1967. Preliminary models for accumulation of organic matter in an Eriophorum-Colluna ecosystem. Aquila, Ser. Botanica, 6: 297-313.

HANSON, H. C. 1953. Vegetation types in northwestern Alaska and comparisons with communities in other arctic regions. Ecology, 34: 111-40.

HARDIN, G. 1968. The tragedy of the commons. Science, 162: 1243-48.

HEUSSER, C. J. 1965. A Pleistocene phytogeographical sketch of the Pacific Northwest and Alaska. In: H. E. Wright and D. G. Frey, eds. The Quaternary of the United States. Princeton: Princeton University Press: 469-83.

HILL, D. E. and J. C. F. TEDROW. 1961. Weathering and soil formation in the arctic environment. American Journal of Science, 259: 84-101.

HOBRIE, J. E. 1964. Carbon 14 measurements of primary production in two Alaskan Lakes. International Association of Theoretical and Applied Limnology. Verhandlungen, 15: $360-64$.

HoDgson, H. J. 1966. Floral initiation in Alaskan Gramineae. Botanical Gazette, 127: 64-70.

HOLMES, R. T. 1966. Feeding ecology of the Red-backed Sandpiper (Calidris alpina) in Arctic Alaska. Ecology, 47: 32-45.

HOLMES, R. T. and F. A. PITELKA. 1968. Food overlap among co-existing sandpipers on northern Alaskan tundra. Systematic Zoology, 17, (3): 305-18.

HOPKINS, D. M. and R. S. SIGAFOos. 1951. Frost action and vegetation patterns on Seward Peninsula, Alaska. U.S. Geological Survey Bulletin 974-C: 51-100.

HULTÉN, ERIC. 1968. Flora of Alaska and neighboring territories: a manual of the vascular plants. Stanford: Stanford University Press. 1008 pp.

Johnson, P. L. and W. D. BILLINGS. 1962. The alpine vegetation of the Beartooth Plateau in relation to cryopedogenic processes and patterns. Ecological Monographs, 32: 105-35.

JOHNSON, P. L. and J. J. KELley. 1969. Dynamics of carbon dioxide in an arctic biosphere. Ecology (In Press). 
Johnson, A. W. and J. G. PACKeR. 1965. Polyploidy and environment in arctic Alaska. Science, 148: 237-39.

JOHNSON, A. W., J. G. PACKER and G. REESE. 1965. Polyploidy, distribution and environment. In: H. E. Wright and D. G. Frey, eds. The Quarternary of the United States. Princeton: Princeton University Press, pp. 497-507.

JOHNSON, A. W., L. A. VIERECK, R. E. JOHNSON and H. MELCHOIR. 1966. Vegetation and flora. In: N. J. Wilimovsky and J. N. Wolfe, eds. Environment of the Cape Thompson Region, Alaska. Oak Ridge, Tennessee: U.S. Atomic Energy Commission. pp. 277-354.

KALFF, J. 1967a. Phytoplankton abundance and primary production rates in two arctic ponds. Ecology, 48: 558-65.

1967b. Phytoplankton dynamics in an arctic lake. Journal of the Fisheries Research Board of Canada, 24: 1861-71.

1968. Some physical and chemical characteristics of arctic fresh waters in Alaska and northwestern Canada. Journal of the Fisheries Research Board of Canada, 25: 2575-87.

KROG, HILDUR. 1968. The macrolichens of Alaska. Norsk Polarinstitutt Skrifter Nr. 144: $1-180$.

LIKENS, G. E. and P. L. JOHNSON. 1968. A limnological reconnaissance in interior Alaska. U.S. Army CRREL Research Report, 239: 21-41.

LövE, A. and D. Löve. 1957. Arctic polyploidy. Genetical Society of Canada, Proceedings, 2: 23-27.

MAYER, w. v. 1954. Food consumption patterns in the Arctic ground squirrel, Spermophilus undulatus. Anatomical Record, 120: 760.

MOONEY, H. A. and W. D. BILLINGS. 1960. The annual carbohydrate cycle of alpine plants as related to growth. American Journal of Botany, 47: 594-98.

MOONEY, H. A. and A. W. JOHNSON. 1965. Comparative physiological ecology of an arctic and an alpine population of Thalictrum alpinum L. Ecology, 46: 721-27.

MULLEN, D. A. 1968 . Reproduction in brown lemmings (Lemmus trimucronatus) and its relevance to their cycle of abundance. University of California Publications in Zoology, 85: 1-24.

ODUM, E. P. 1969. The strategy of ecosystem development. Science, 164: 262-70.

PACKer, J. G. 1969. Polyploidy in the Canadian Arctic Archipelago. Arctic and Alpine Research, 1: 15-27.

PÉWÉ, T., D. M. HOPKINS and J. L. GIDDINGS. 1965. The Quaternary Geology and Archaeology of Alaska. In: H. E. Wright and D. G. Frey, eds. The Quaternary of the United States. Princeton: Princeton University Press: 355-74.

PITELKA, F. A. 1957. Some aspects of population structure in the short term cycle of the Brown Lemming in Northern Alaska. Cold Spring Harbor Symposia on Quantitative Biology, 22: 237-51.

- 1959. Numbers, breeding schedule, and territoriality in Pectoral Sandpipers of Northern Alaska. Condor, 61: 233-64.

PITELKA, F. A., P. Q. TOMICH, and G. W. TREICHEL. 1955. Ecological relations of jaegers and owls as lemming predators near Barrow, Alaska. Ecological Monographs, 25: 85-117.

PITElKA, F. A. and A. M. SCHultz. 1965. The nutrient recovery hypothesis for arctic microtine cycles. In: Grazing in terrestrial and marine environments. Oxford: Blackwell Scientific. pp. 55-68.

RUSSELL, R. S. 1940a. Physiological and ecological studies on an arctic vegetation. II. The development of vegetation in relation to nitrogen supply and soil micro-organisms on Jan Mayen Island. Journal of Ecology, 28: 269-88. 
RUSSELL, R. S. 1940b. Physiological and ecological studies on an arctic vegetation. III. Observations of carbon assimilation, carbohydrate storage and stomatal movement in relation to the growth of plants on Jan Mayen Island. Journal of Ecology, 28: 289-309.

SIGAFOOS, R. S. 1952. Frost action as a primary physical factor in tundra communities. Ecology, 33: 480-87.

SPETZMAN, L. A. 1959. Vegetation of the Arctic Slope of Alaska. U.S. Geological Survey Professional Paper, 302-B: 19-58.

STEERE, w. C. 1965 . The boreal bryophyte flora as affected by Quaternary glaciation. In: H. E. Wright and D. G. Frey, eds. The Quaternary of the United States. Princeton: Princeton University Press: 485-95.

TEDROW, J. C. F. and J. BRown. 1968. Soils of Arctic Alaska. In: H. E. Wright, Jr. and W. H. Osburn, eds. Arctic and Alpine Environments. Bloomington: Indiana University Press: pp. 283-94.

TEDRow, J. C. F. and J. E. CANTLON. 1958. Concepts of soil formation and classification in Arctic Regions. Arctic, 11: 166-79.

TEDRoW, J. C. F., J. V. DREW, D. E. HILL and L. A. Douglas. 1958. Major genetic soils of the Arctic Slope of Alaska. Journal of Soil Science, 9: 33-45.

THOMPson, D. Q. 1955. The role of food and cover in population fluctuations of the brown lemming at Point Barrow, Alaska. 20th North American Wildlife Conference Transactions. pp. 166-76.

TIESZEN, L. L. and E. K. BONDE. 1967. The influence of light intensity on growth and chlorophyll in arctic, subarctic and alpine populations of Deschampsia caespitosa and Trisetum specatum. University of Colorado Studies, Series in Biology, 25: 1-21.

TIESZEN, L. L. and J. A. HELGAGER. 1968. Genetic and physiological adaptation in the Hill reaction of Deschampsia caespitosa. Nature, 219(5158): 1066-67.

TIESZEN, L. L. and P. L. JOHNSON. 1968. Pigment structure of some arctic tundra communities. Ecology, 49: 370-73.

TIKHomirov, B. A. 1963. Contribution to the biology of arctic plants (in Russian). Ocherki po biologiĭ rasteniĭ Arktiki. Akademiia Nauk U.S.S.R. 154 pp.

TROLL, C. 1958. Strukturboden, Solifluktion and Frostklimate der Erde. Hanover: U.S. Army CRREL. Translation 43. $121 \mathrm{pp}$.

UGolini, F. C., J. C. F. TEDRow, and C. L. GRANT. 1963. Soils of the Northern Brooks Range, Alaska. 2. Soils derived from black shale. Soil Science, 95: 115-23.

VIERECK, L. A. 1966. Plant succession and soil development on gravel outwash of the Muldrow Glacier, Alaska. Eçological Monographs, 36: 181-99.

WAGER, H. G. 1938. Growth and survival of plants in the Arctic. Journal of Ecology, 26: $390-410$.

WARREN-WILSON, J. 1960. Observation on net assimilation rates in arctic environments. Annals of Botany, new series, 24: 372-81.

1966. An analysis of plant growth and its control in arctic environments. Annals of Botany, new series, 30: 383-402.

WEBER, N. A. 1950. A survey of the insects and related arthropods of Arctic Alaska, Part I. American Entomological Society Transactions, 76: 147-206.

WEEDEN, R. B. 1969. Arctic oil: its impact on wilderness and wildlife. In: Proceedings of the 11th Biennial Wilderness Conference. San Francisco, California: Sierra Club. (In Press).

WHITE, LYNN, JR. 1967. The historical roots of our ecological crisis. Science, 155: 1203-07.

WIGGINS, I. L. 1951. The distribution of vascular plants on polygonal ground near Point Barrow, Alaska. Stanford University Contributions of the Dudley Herbarium, 4: 41-52.

Wiggins, 1. L. and J. H. THOMAS. 1962. A flora of the Alaskan Arctic Slope. Toronto: University of Toronto Press. 425 pp. 